\title{
Evaluation of business ethics for the formation of public finance
}

\section{Vynnychenko Nataliia}

Associate Professor, Chair of Accounting and Taxation, Academic and Research Institute of Business Technologies "Ukrainian Academy of Banking", Sumy State University, Sumy, Ukraine

\section{Majewska Urszula}

\author{
Coordinator "Dreamers and Craftsmen. Social Innovations House", Warsaw, Poland \\ (C) The Authors, 2017. This article is published with open access at ARMG Publishing.
}

\begin{abstract}
The analysis of modern approaches to defining the essence of basic categories which form an idea of the impact of business ethics on public finances is carried out in the article. The main components of the system of public finance are determined; it is presented as a combination of three elements: public finance, local finance and finance of public organizations of charities and other public entities, funds of which are of public nature and are directed at solving social problems.

The aim of the article is the study of existing approaches to determination of basic categories of relationship "business ethics - public finance", the analysis of the current condition and trends of business ethics impact and the development of the evaluation model of such an impact on public finance.

It is determined that the main areas of business ethics impact on public finance is the influence through the tax deduction system and the system of charitable and sponsor contributions.

The author's evaluation model of business ethics impact on public finance is suggested and the basic set of factors that both directly and indirectly carry out such an influence is defined. It was determined that the business ethics impact on public finance should be investigated both from the standpoint of influence and from the perspective of the results received.

The analysis of the current state of business ethics impact on public finance shows that the role of ethics as one of the influencing factors is not sufficiently taken into account and requires further research and practical developments.
\end{abstract}

Keywords: business ethics, public finance, ethics charity, local finance.

JEL Classification: G00.

\section{Introduction}

Stable transformation of economy in recent years and the necessity of overcoming the systemic crisis require significant changes in relation of business public finances and the need to develop new integrated approaches to establish clear causal relationships between business development and its impact on economy generally and the formation of public finances in particular. Overregulation of the economy in Ukraine led to the establishment of significant restrictions for business and had a negative impact on further growth of economic processes, and, thus, the formation of public finances. Recently, except legal restrictions, the public sector influences greatly on business processes by establishing ethical constraints for business development. Restricting of foreign markets and the loss of raw materials channels led to significant economic losses and the need for reorientation to other markets and sales channels of raw materials.

The emergence of ethical limits in the domestic enterprises and deterioration of domestic business in particular and economy in general necessitate the development of integrated approaches to impact assessment component of ethical business operation on economic development and the formation of public finances.

Over the past decade the issue of determination of the effect of different kinds of factors on the formation of public finance is studied by many economic schools and scientific trends. So, the question of formation and distribution of public finances in the economic literature was studied by a significant number of foreign and domestic scientists such as W. Baska, Beydzhhot William M. Bunge, A. Vasiliko, R. Gilferdinh, D. Hetmantsev, D. Keynes, A.T. Kirilenko, K. Marx, Ivan Miklos, J. Mill, V. Oparin, K. Rau, J. Pasichnk, A. Smith, Paul Samuelson, A. Sokolovskaya, Schumpeter, P. George, David Hume and many others. In turn, 
business ethics issues addressed in the work of such scholars as R. Almeder, James. Walsh, T. Donaldson, A. Zalyubivska, A. Lesko, M. Pryschak, G. Ruzakova, J. Sundberg, M. Snoyenbos, John Humber, V. Shaw and others who developed the basic foundation of business ethics as a separate scientific direction. But despite the high interest to essence question and importance of business ethics in all areas of management, the assessment question of the impact of business ethics on the formation of public finances is not opened enough.

Under modern conditions of state and public regulation of financial relations, the idea of their generation and distribution is based on the usage of ethical and social elements of development in many areas, including the development of business environment. In the context of determining the effect of business ethics on public finances there is a need to clarify the categorical apparatus and study key indicators of such evaluation, including such key categories as "business ethics" and "public finances".

In domestic literature business ethics is considered as a part of the ethics of business relations, which contradicts the very essence of this concept, because, in our opinion, the concept of business already includes the sphere of business relationship. Approaches to defining the essence of this concept are summarized in Table. 1.

Table 1. Approaches to defining the essence of the concept of "ethics bizes"

\begin{tabular}{|l|l|}
\hline \multicolumn{1}{|c|}{ Source } & \multicolumn{1}{c|}{ The definition } \\
\hline Investopedia [1] & $\begin{array}{l}\text { The study of proper business policies and practices regarding potentially controversial issues, such as corporate } \\
\text { governance, insider trading, bribery, discrimination, corporate social responsibility and fiduciary } \\
\text { responsibilities. Law often guides business ethics, while sometimes business ethics provide a basic framework } \\
\text { that businesses may choose to follow to gain public acceptance. }\end{array}$ \\
\hline Wikipedia [2] & $\begin{array}{l}\text { A form of applied ethics or professional ethics that examines ethical principles and moral or ethical problems } \\
\text { that arise in a business environment. It applies to all aspects of business conduct and is relevant to the } \\
\text { behavior of individuals and entire organizations.These ethics originate from individuals, organizational } \\
\text { statements or from the legal system. }\end{array}$ \\
\hline Brian Schrag [3] & $\begin{array}{l}\text { Ethics programs convey corporate values, often using codes and policies to guide decisions and behavior, and } \\
\text { can include extensive training and evaluating, depending on the organization. They provide guidance in ethical } \\
\text { dilemmas. }\end{array}$ \\
\hline $\begin{array}{l}\text { Donaldson, T., } \\
\text { Walsh J.P. [4] }\end{array}$ & $\begin{array}{l}\text { The study of ethical dimensions of productive organizations and commercial activities. This includes ethical } \\
\text { analyses of production, distribution, marketing, sale, and consumption of goods and services }\end{array}$ \\
\hline Dictionary [5] & $\begin{array}{l}\text { The study and examination of moral and social responsibility in relation to business practices and decision- } \\
\text { making in business. }\end{array}$ \\
\hline Joakim Sandberg & $\begin{array}{l}\text { The application of ethical theories and concepts to activity within and between commercial enterprises, and } \\
\text { between commercial enterprises and their broader environment. It is a wide range of activity, and no brief list } \\
\text { can be made of the issues it raises. The safety of working practices; the fairness of recruitment; the transparency } \\
\text { of financial accounting; the promptness of payments to suppliers; the degree of permissible aggression between } \\
\text { competitors: all come within the range of the subject. }\end{array}$ \\
\hline M. Toftul [7] & $\begin{array}{l}\text { A part of the ethics of business relations, which explores the features and operation of ethics in business, } \\
\text { commercial activities and formulates appropriate recommendations in this sphere. }\end{array}$ \\
\hline
\end{tabular}

In foreign practice business ethics is considered as a part of classical ethics, which examines the behavior of business in society, and a special role in the study of these questions belongs to D. Breybruku in particular. In turn, overseas study focuses even on a narrower terms than business ethics, including the ethics of competitive relations, ethics in the middle of relations, including workers, the ethics of relations with public authorities, in terms of taxes in particular, ethics in relation to society. There is no doubt, that business has influence on the social and economic situation on the ground and through both direction and through the implementation of various kinds of programs such as: charitable, educational, investment. And, today, there is a number of approaches to assess such effects as by determining social and economic impact (social economic impact assessment - SEIA) and through the definition of social efficiency of investments (social return on investment - SROI), by applying the model of the London Benchmarking Group (LBG) and life cycle assessment (LCA). These techniques allow to assess the presence of business in society of a certain region from different perspectives. However, the assessment question of the impact of business ethics in public finances remains opened, as the understanding of the very essence of public finances. Basic approaches to define the essence of the category of "social finance" are presented in Table 2. 
Table 2. Approaches to define the essence of the concept of "social (public) finances"

\begin{tabular}{|l|l|}
\hline \multicolumn{1}{|c|}{ Source } & \multicolumn{1}{|c|}{ The definition } \\
\hline M. Carlin [8] & $\begin{array}{l}\text { include state and local finances, which differ among themselves as subjects, or objects of financial } \\
\text { relations; } \\
\text { relationships and processes associated with the formation and use of public money, providing the } \\
\text { functioning of public sector. }\end{array}$ \\
\hline A Derlytsya. [9] & $\begin{array}{l}\text { Qualitative state of the financial management of the country, the most acceptable and beneficial form } \\
\text { of centralized public funds. }\end{array}$ \\
\hline I. Rozputenko [10] & $\begin{array}{l}\text { Monetary system resources belongs to the state and it is designed to meet inherent state of economic, } \\
\text { social and political functions, and a set of forms and methods by which these funds are formed. }\end{array}$ \\
\hline C Luchkovska. [11] & $\begin{array}{l}\text { Financial resources to meet the needs of the whole society or its individual parts. Their distributor is } \\
\text { the state represented by EFA and CBOs. }\end{array}$ \\
\hline S.O. Koretskaya [12] & $\begin{array}{l}\text { Public finance in conjunction with the local (municipal) and other public funds form the public } \\
\text { finances. Despite the relative independence of state and local finances within the state, public finances } \\
\text { are the only category of devices that confirmed the unitary state; unity of monetary system, economic, } \\
\text { financial and customs policy; unity of state and local control and regulation of financial system. }\end{array}$ \\
\hline O. Moldavan [13] & $\begin{array}{l}\text { System of economic relations between the state, corporations and individuals, and also between } \\
\text { individual states and international financial institutions regarding the accumulation and use of funds. }\end{array}$ \\
\hline Business dictionary [14] & $\begin{array}{l}\text { Collection of taxes from those who benefit from the provision of public goods by the government, and } \\
\text { the use of those tax funds toward production and distribution of public goods. }\end{array}$ \\
\hline $\begin{array}{l}\text { The Law of Ukraine } \\
\text { "About open use of public } \\
\text { funds" [15] }\end{array}$ & $\begin{array}{l}\text { The state budget of Ukraine and local budgets, loans granted under the state and local guarantee funds } \\
\text { of National Bank and other state-owned banks, state trust funds, pension fund and funds of social } \\
\text { insurance funds and entities of state and municipal property received from their economic activities. }\end{array}$ \\
\hline
\end{tabular}

In domestic literature the category of public finances is often equated with the concept of public finances, though, there is another approach which is in the public finance and considers this component as the local finance. Approaches to research the definition of public finance and understanding other aspects which directly related to this category and indicate that the category of "social finance" is much broader and is not limited by the resources of state and local budgets and includes other resources which, by existing legislation, are open for understanding their nature, the analysis of movement, and free access to information on them. Thus, in our opinion, the most comprehensive approaches are those which based on the isolation of three main components of public finance: state funds, local budgets and funds of the third sector (public and charitable entities). Thus, the structure of public finance can be provided as Figure 1.

Considering the analysis of approaches to define the essence of such basic concepts as "business ethics" and "public finances", it is necessary to determine that the impact of the ethical and moral values on business environment, which is aimed at the formation of financial resources, and mainly it is carried out through the mechanism of collection of taxes, fees and charges and the actual desire of business participation to solve social problems through charitable contributions and donations.

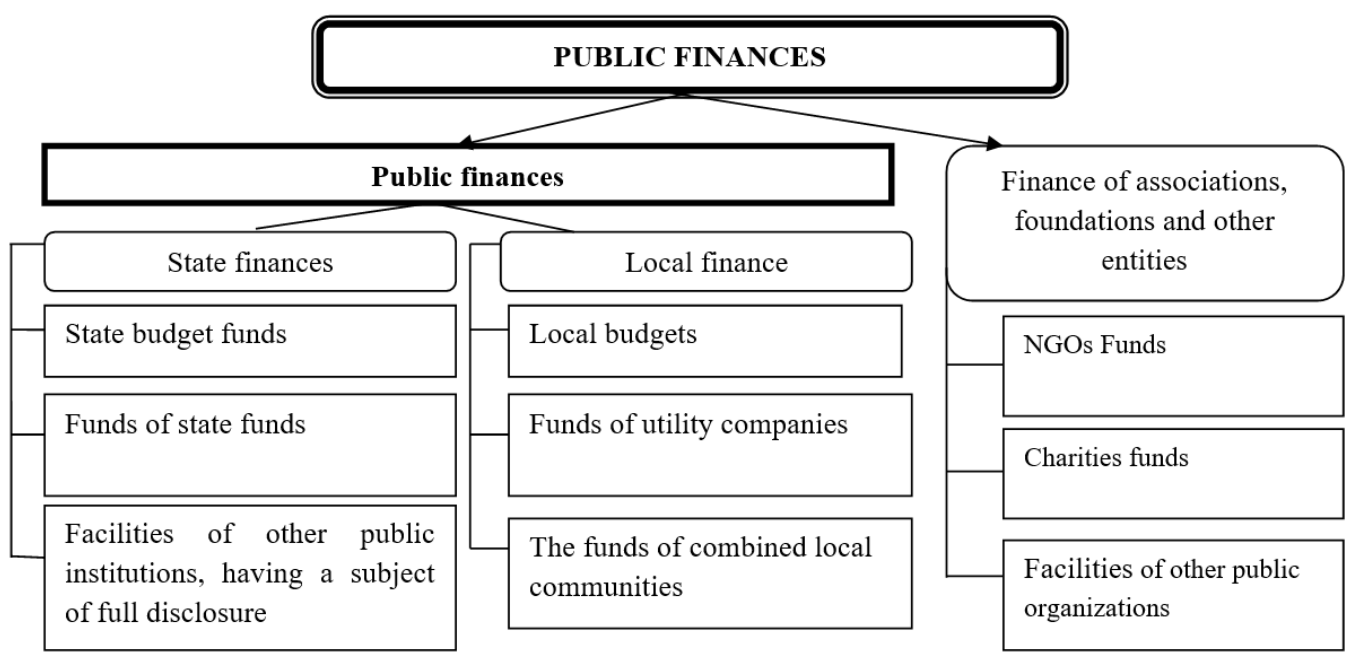

Figure 1. The main components of public finance 
During the study of business ethics influence on the formation of public finances, it should be noted that such effects must be considered in the context of two components: direct impact and consequences. In particular, if you consider a question of business responsibility for the completeness and timeliness of taxes, payments, it seems that the main issue is clearly regulated by law. But from an ethical point of view there is a question of tax optimization and tax evasion via actions or inactivity that is not against the law. Such optimization is nothing more than the habit trained in domestic business practice. The desire to pay little taxes to the budgets of all levels, at the level of morality, is not considered as a negative development for the majority of business environment in Ukraine and abroad. But, internationally over the last decade a number of documents have been adopted, which aimed at both the elimination of direct illegal tax evasion and legal tax optimization of load which is considered unethical. A significant role in the study of ethics of tax optimization belongs to American scientist Robert McGee, author of Ethics Tax Evasion, who distinguishes these three approaches to determine ethical issue of tax optimization. The first approach is based on full immorality with tax evasion. The second approach is based on the obligation to pay taxes because business has obligations to society. The third approach has religious foundations and based on the morality of paying taxes and obliges to pay all taxes. [16]. The ethical component of tax optimization explained by the causes of tax evasion, the high tax burden, corruption in the process of spending public finance, taxation, injustice process etc. However, the author notes that the ethical side of the obligation to pay taxes is based on the moral education of business and tax culture. The article [17] says that the level of tax culture depends on overall spiritual, social, and psychological climate in society, the values and norms that prevail among government, business, culture and public due to broadcast media.

We should not also forget about public finance component, which is formed by NGOs, charities, etc., and through a business desire to implement social transformation. The motivation is the desire of changes that can be implemented on business expense. Charity arises as a part of businesses training of moral obligations to society. In recent years the number of civic and charitable organizations significantly increased. But, in general, this is not a growth of business ethics and morality, but this is a use of charitable and community organizations in their own selfish purposes: forming a political portrait, profits reduce, a positive image of the company. The need of real, charity is generated by an urgent solving of social issues. The development of charity, philanthropy, sponsorship would seem to exist in under developed countries, but in recent years on the contrary, new culture of charity has been formed. In recent years the ethics of charity, not just business ethics in Ukraine in Poland, is considered much less. The analysis of legal regulation of charitable activities in two countries indicates the existence of more clear legislation of the activities of charities in Poland than in Ukraine. But it is also not perfect and has some weak sides. Nowadays, there is a need to develop a separate regulatory document on the activities of charities in Ukraine. The main current regulatory instrument is the Law of Ukraine "On charity and charitable organizations" which repeatedly investigated and was a subject of criticism. But the vast majority of scientists emphasize that any changes will not resolve the conflict as ensuring the formation of the ethics and culture of charity. 


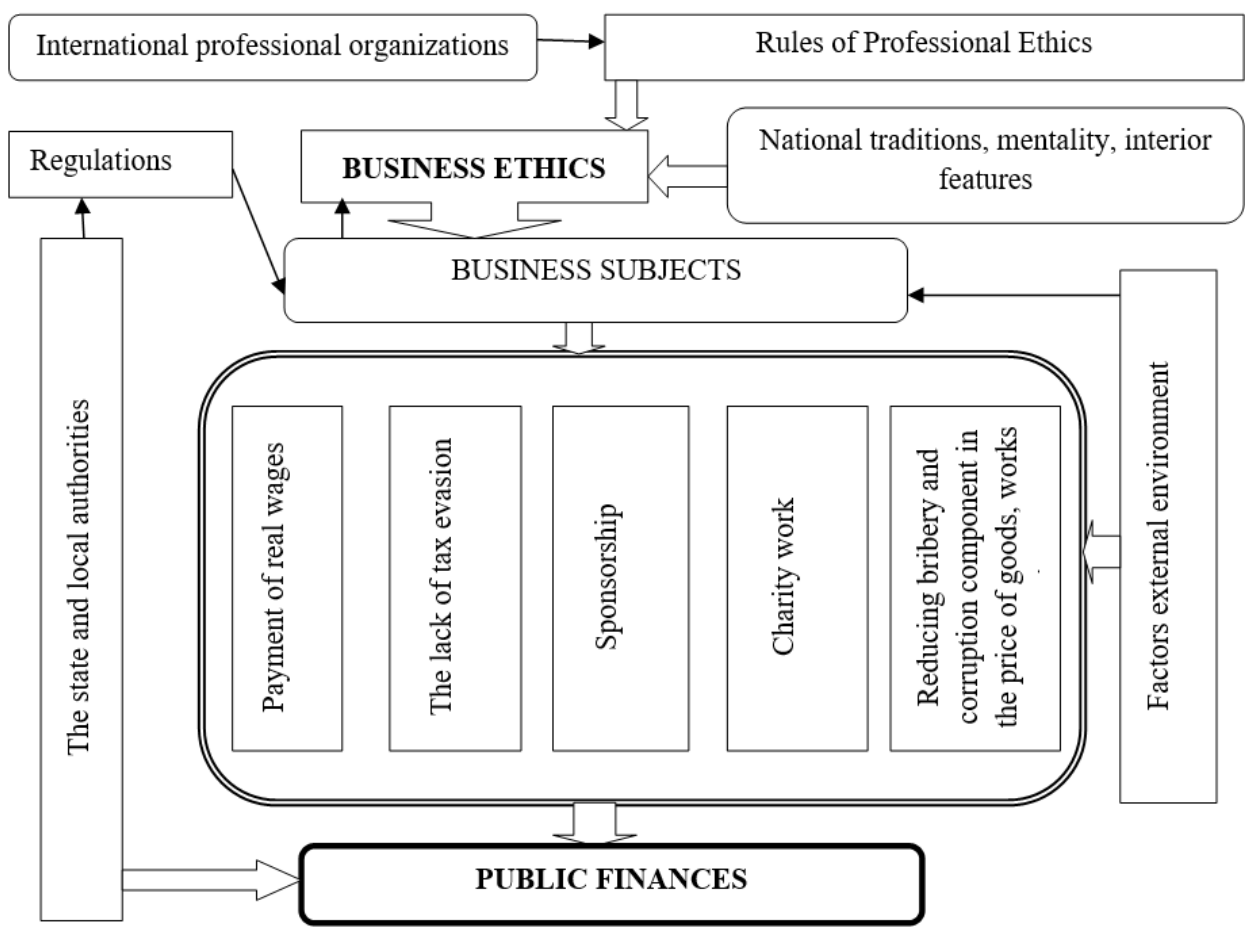

Figure 2. Business model impact on public finances of ethics

Exploring the impact of business ethics on the formation of public finances, you should not forget about indirect influence of certain factors. Among the leaders of these factors are corrupt business activities. In recent decades people try to fight with this fact. The achievement of recent years is the introduction of electronic procurement in a national practice. This step allows to avoid large-scale corruption violations, but the business and customers of goods and services began to learn new mechanisms of manipulation in the system of public procurement in the form of budget funds. Under such conditions, it is necessary to increase the level of business ethics and values formation that will facilitate the establishment of ethical barriers ensuring the avoidance of corruption component, and therefore, as a result, will increase the efficiency of public finance.

Business ethics is one of the factors that influence the formation of public finances. Conventionally, the formation of public finances and the impact of business ethics can be defined.

Business ethics is influenced by international professional organizations, legislation and mentality, traditions and more. The prevailing moral values may vary depending on conditions (environmental factors). The activities of undertakings depends on prevailing moral and ethical values and existing legislation. Public finances increases if real wages are paid, and taxes on personal income are sent to the budgets and funds, businesses do not evade taxes, make charitable help and sponsorship, and operate transparently in the market.

So, of course, business ethics in domestic practice is a phenomenon that is not sufficiently formed, however, that ethical rules and barriers affect the of business conduct. Sometimes ethical restrictions are more effective, than a legislative rules and restrictions. That is why, there is a need not only to understand the impact of business ethics in economic processes, but also to develop integrated approaches to assessing its impact on such processes in general and on the development of public finances in particular.

\section{References}

1. Definition of Business Ethics. Investopedia. Retrieved from: http://www.investopedia.com/ terms/b/business-ethics.asp\#ixzz4Zjd3JSgF

2. Definition of Business Ethic. Retrieved from:https://en.wikipedia.org/wiki/Business_ethics

3. McNamara Carter, Complete Guide to Ethics Management: An Ethics Toolkit for Managers, MBA, PhD, Authenticity Consulting, LLC// Retrieved from: http://managementhelp.org/businessethics/ethicsguide.htm

4. Donaldson, T. \& J.P. Walsh (2015). "Toward a Theory of Business". Research in Organizational Behavior, $35 ; 181-207$. 
5. Definition of Business Ethics. Retrieved from: http://www.dictionary.com/browse/business-ethics.

6. Sandberg, J. (2010). Business Ethics. Retrieved from: https://www.rep.routledge.com/article/L009.

7. Toftul, M. (2011). Ethics for schools. 2 Nd ed., Straighten, Reported. K. Academy, 437 p.

8. Carlin, M. (2016). Public Finance in a democracy. Luck Tower printing, 160 p.

9. Kyrylenko, A.P. (2016). Second reading scientific memory SI George: Collected Works. For hypertension. Doctor of Economics, professor. - 28 November 2016, Ternopil: TNEU, $184 \mathrm{p}$.

10.Public finances: teaching guidances. Discipline "Public Finance". (2008). K: NAPA. 48 p.

11. Luchkovska, S.I. (2010). Financial Law: Teaching Manual. - K .: CST, 296 p.

12.Koretskaya, S.O. (2011). Analysis of categorical apparatus of public finance. Investments Practice and Experience. 19, 25-27

13.Moldovan, A.A. (2011), Public finances in Ukraine: experience and prospects for reform [monograph]. K $\therefore$ NISS, $380 \mathrm{p}$.

14.Definition of public finance. Retrieved from: http://www.businessdictionary.com/definition/publicfinance.html.

15.On the open use of public funds: Law of Ukraine of 11.02.2015. Number 183 VIII. [Electronic resource]. Retrieved from: http://zakon5.rada.gov.ua/laws/show/183-19.

16.MacGee, P.W. (2012). The Ethics of Tax Evasion. Springer. 339 p.

17. Bashynsky, I. (2014). Ways and means of implementing the state policy on the formation of tax culture. Proceedings of the population. Governance, 242 (230), 11-14. 